\title{
Pearls \& Oy-sters: Primary angiitis of the CNS presenting with recurrent intracranial hemorrhage
}

Jessica Rice, MD, Randall Woltjer, MD, PhD, Nicholas Stienstra, MD, Elizabeth Sun, MD, and Vijayshree Yadav, MD

Neurology ${ }^{\circledR}$ 2020;94:e992-e995. doi:10.1212/WNL.0000000000009047
Correspondence

Dr. Rice

ricejes@ohsu.edu

\section{Pearls}

- Primary angiitis of the CNS (PACNS) is a rare small or medium vessel vasculitis confined to the CNS.

- There is no characteristic presentation, but symptoms commonly include headache, focal neurologic changes, cognitive changes, and ischemic stroke.

- Treatment most commonly includes a combination of high-dose corticosteroids and IV cyclophosphamide infusions. However, their use is derived from a few small retrospective observational studies.

\section{Oy-sters}

- Conventional cerebral angiogram can miss small vessel changes. Brain biopsy remains the gold standard for diagnosis.

- Serum markers of inflammation can be normal.

- Reversible cerebral vasoconstriction syndrome (RCVS) is a common mimic of PACNS. Thunderclap headache and transient areas of segmental narrowing on angiogram can help differentiate RCVS from PACNS.

- In patients with recurrent intraparenchymal hemorrhage (IPH) without a clear explanation, it is important to keep PACNS on the differential diagnosis.

A 23-year-old right-handed man presented to the hospital with acute onset of left hemiparesis, numbness, and dysarthria. CT head showed a right frontal IPH. The patient was transferred to a tertiary care center as he had experienced 2 previous IPHs of unclear etiology in the 4 months prior to admission.

The patient initially presented 4 months previously with generalized tonic-clonic seizure, and workup revealed a right parietal IPH on head CT. Brain MRI with and without contrast showed multiple small areas of susceptibility signal in the deep white matter concerning for microhemorrhages, leptomeningeal enhancement over the right parietal lobe, and an area of parenchymal enhancement in the right temporal lobe. Cerebral angiogram was performed instead of CT or magnetic resonance angiogram to evaluate for vascular malformations. Angiogram showed subtle multifocal areas of narrowing in the right middle cerebral artery (figure, D) with tapered appearance of the bilateral intracranial internal carotid arteries of unknown significance. C-reactive protein (CRP) was elevated at 70.5 , erythrocyte sedimentation rate (ESR) was mildly elevated at 24, but antineutrophil cytoplasmic antibodies (ANCA), antinuclear antibodies, CSF oligoclonal bands (OCBs), and immunoglobulin G (IgG) synthesis rate/index were within normal limits. The patient's blood pressure was normal. The patient was discharged home per his request before final diagnosis was made. He had a normal neurologic examination, maintenance antiseizure medication, and a plan for outpatient brain MRI in 4-6 weeks. 
Two months after sentinel presentation, the patient presented with acute onset of word-finding difficulties and headaches, and was found to have an acute left frontal lobe IPH. Brain MRI showed multiple new microhemorrhages, but no new areas of contrast enhancement. Repeat angiogram did not redemonstrate areas of segmental narrowing. Repeat CRP was normal. His symptoms resolved within days, and his neurologic examination was normal. Given the resolution of segmental narrowing on cerebral angiogram, he was diagnosed with RCVS, thought to be precipitated by daily cannabis use. The patient was discharged home with instructions to stop cannabis use.

Two months later, the patient presented again with left-sided weakness and dysarthria, which improved over several days. Brain MRI redemonstrated known areas of hemorrhage, but showed multiple new areas of microhemorrhage throughout the superficial and deep supratentorium, with multiple curvilinear areas of contrast enhancement (figure, E and F), raising concern for vasculitis. Lumbar puncture was performed and was notable for lymphocytic pleocytosis $\left(67\right.$ cells $/ \mathrm{mm}^{3}$, normal 0-5 cells $/ \mathrm{mm}^{3}, 94 \%$ lymphocytes), elevated protein level (94 $\mathrm{mg} / \mathrm{dL}$, normal 15-45 mg/dL), 3 OCBs, and elevated IgG index (1.05, normal $0.28-0.66$ ratio) and $\operatorname{IgG}$ synthesis rate (32.4 mg/d, normal $<8.0 \mathrm{mg} / \mathrm{d}$ ), supporting evidence for CNS inflammation. CSF red blood cell count was elevated $(3,000$ cells $/ \mathrm{mm}^{3}$ ), likely due to acute IPH. CSF glucose level was normal. Serum inflammatory workup with CRP, ESR, complement, ANCA, rheumatoid factor, and serum protein electrophoresis were within normal limits. Infectious workup for hepatitis $B$, hepatitis $C, H I V$, rapid plasma reagin, and herpes simplex virus CSF was negative. Quantiferon gold was weakly positive, raising concern for latent tuberculosis given a history of exposed family members. Infectious disease was consulted and believed the quantiferon likely represented a false-positive result, but recommended treatment with rifampin out of caution. CT of the chest, abdomen, and pelvis was negative for signs of infection or neoplasm.

Given diagnostic uncertainty, a brain biopsy was obtained (figure, A-C) instead of repeat vessel imaging. Pathology showed small vessel inflammation consistent with a chronic and active vasculitis. There was focal granuloma formation

Figure Pathologic findings associated with primary angiitis of the CNS (PACNS) and brain MRI

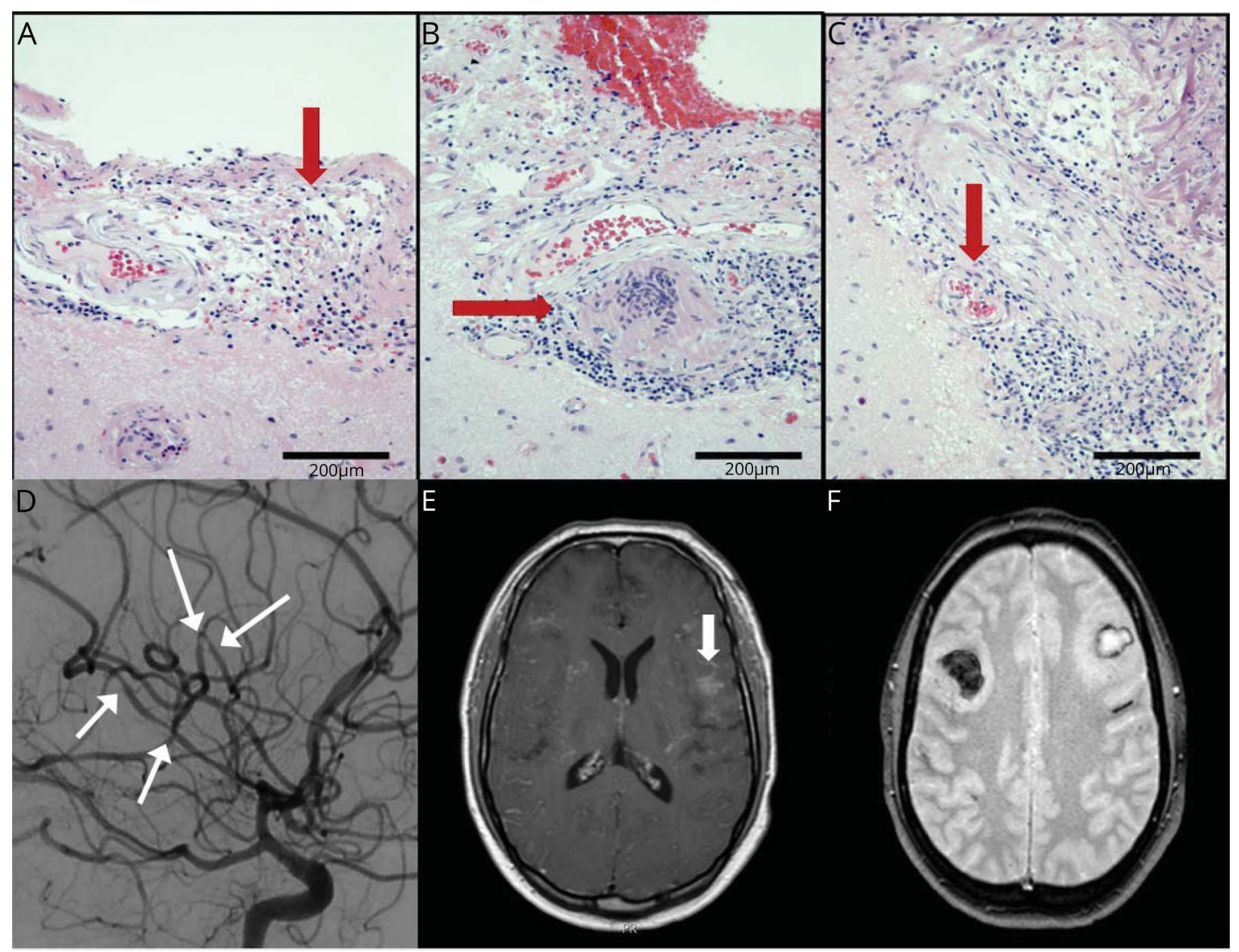

(A) Leptomeningeal surface with diffuse mononuclear infiltrate (arrow, upper portion of figure) extending into superficial cortex (lower portion of figure). (B) Leptomeningeal vascular and perivascular inflammation with focal granuloma formation (arrow). (C) Some leptomeningeal vessels show complete obliteration with fibrotic lumens and transmural inflammation (arrow). (D) Cerebral digital subtraction angiography, sagittal view, shows subtle areas of multifocal narrowing in the right middle cerebral artery (arrows). (E) Axial contrast-enhanced T1-weighted image shows left frontal lobe and diffuse leptomeningeal enhancement (arrow). (F) T2*-weighted image shows multiple hemorrhages of different ages in the right and left frontal lobes. Scale bars: $200 \mu \mathrm{m}$. 
with associated leptomeningitis and cerebritis. Acid fast stain was negative, fungal and bacterial cultures had no growth, and 15 s ribosomal RNA infection panel was negative. The patient was treated with methylprednisolone $1,000 \mathrm{mg} \mathrm{IV} \times 5$ days. $\mathrm{He}$ was discharged on an oral prednisone taper starting at $100 \mathrm{mg}$ prednisone, decreased by $20 \mathrm{mg}$ every 2 weeks. Bacterial PCR results returned negative about 1 week later, and the patient was started on cyclophosphamide $600 \mathrm{~g} / \mathrm{m}^{2}$ monthly for 6 doses with a plan for maintenance with azathioprine afterwards. While on high-dose chronic steroid treatment, the patient was prescribed Bactrim DS daily for Pneumocystis jiroveci pneumonia prophylaxis, as well as vitamin D and calcium supplementation to prevent osteoporosis.

\section{Discussion}

PACNS is a small or medium vessel vasculitis confined to the CNS, affecting the brain parenchyma, spinal cord, and meninges. ${ }^{1}$ It is rare, with an annual incidence of 2.4 cases per $1,000,000$ person-years. ${ }^{2}$ When patients present with vasculitis affecting the CNS, it is most likely secondary to a systemic inflammatory disease. Diagnosis can be challenging, as there is no pathognomonic laboratory result, and CT and magnetic resonance angiography are neither sensitive nor specific. Although brain biopsy remains the gold standard, it has low specificity, ${ }^{3}$ with false-negative rates of $25 \%-50 \%$. $^{1}$ Presenting symptoms can be variable and nonspecific. Patients can experience headache, focal neurologic deficits, cognitive impairment, TIA, and ischemic stroke. ${ }^{1,2}$ Intracranial hemorrhage (ICH) is a less common manifestation, but it may be underrecognized in relation to PACNS. A 2011 cohort study of people with PACNS found that $12.1 \%$ of people studied over a 25 -year period had ICH near or at the time of diagnosis. ${ }^{4}$ However, a recent cohort study of 60 patients found ICH in 55\% of the cohort. ${ }^{5}$ Although the data are limited, they suggest that PACNS may present with $\mathrm{ICH}$ more commonly than previously thought. This case underscores the importance of including PACNS in the differential diagnosis for patients with unexplained $\mathrm{ICH}$.

This case presented a challenging diagnosis, and alternative explanations were considered before a diagnosis of PACNS was made after brain biopsy. In this patient, vasculitis was suspected based on the presentation of recurrent IPH without an alternative explanation, seizure, focal neurologic deficits, segmental narrowing on cerebral angiogram, and recurrent areas of curvilinear enhancement on MRI suggesting vascular involvement. Although some CSF and serum markers of inflammation were elevated, these changes were intermittent and transient. Extensive rheumatologic workup showed no evidence of systemic inflammatory disorder or evidence of vasculitis in another organ system.

After his second admission, the patient was diagnosed with RCVS, a frequent mimic of PACNS. RCVS is characterized by reversible vasoconstriction of the cerebral arteries leading to acute onset of severe headaches, seizures, focal neurologic deficits, and ischemic or hemorrhagic strokes. ${ }^{6}$ These conditions have overlapping features, but can be distinguished in several ways. Both can present with headaches, but RCVS typically presents with thunderclap headache. A recent study found thunderclap headache was absent in only $6 \%$ of patients with $\mathrm{RCVS}^{7}$ and recurrent thunderclap headache had a $100 \%$ positive predictive value for diagnosis of RCVS. ${ }^{8}$ RCVS will often present acutely whereas PACNS can progress over months. ${ }^{8}$ In RCVS, CSF is often normal or can reflect cerebral hemorrhage, if present. ${ }^{9}$ On MRI, PACNS is more likely to show T2-hyperintense lesions, leptomeningeal enhancement, and deep/brainstem infarcts, whereas MRI in RCVS can be normal or show watershed infarcts or vasogenic edema, with $100 \%$ positive predictive value. ${ }^{8}$

RCVS and PACNS can present with segmental narrowing on cerebral angiogram, but this is neither sensitive nor specific for diagnosis of either condition. Segmental narrowing of mediumsized vessels can also be found in vasospasm, atherosclerosis, fibromuscular dysplasia, and moyamoya disease. Resolution of segmental narrowing after a period of 1-3 months may argue for RCVS. ${ }^{10}$ Sensitivity of cerebral angiogram for the diagnosis of PACNS is not high, previously estimated to be about $60 \%$. PACNS can be limited to the small vessels, which is below the resolution of conventional cerebral angiography.

Our patient had several features that added to the difficulty in differentiating between RCVS and PACNS. First, the patient's initial CSF showed evidence of hemorrhage, but other markers of inflammation (CSF protein, IgG synthesis rate/index, OCB) were all within normal limits. The segmental narrowing seen on initial cerebral angiogram resolved on repeat angiogram 2 months later, which is more typical of RCVS. ${ }^{9}$

This case illustrates the diagnostic challenge of an unusual presentation of a rare disease. Intracerebral hemorrhage is an underrecognized presentation of PACNS, and should remain in the differential for patients who present with recurrent hemorrhages. A high degree of clinical suspicion for PACNS is required and brain biopsy remains the gold standard for definitive diagnosis.

\section{Study funding}

No targeted funding reported.

\section{Disclosure}

The authors report no disclosures relevant to the manuscript. Go to Neurology.org/N for full disclosures.

\begin{tabular}{|c|c|c|c|}
\hline Name & Location & Role & Contribution \\
\hline $\begin{array}{l}\text { Jessica } \\
\text { Rice, MD }\end{array}$ & $\begin{array}{l}\text { Oregon Health \& } \\
\text { Science } \\
\text { University, } \\
\text { Portland }\end{array}$ & Author & $\begin{array}{l}\text { Design and } \\
\text { conceptualization of the } \\
\text { study, acquisition and } \\
\text { interpretation of the data, } \\
\text { drafting and revising of the } \\
\text { manuscript }\end{array}$ \\
\hline
\end{tabular}


Appendix (continued)

\begin{tabular}{|c|c|c|c|}
\hline Name & Location & Role & Contribution \\
\hline $\begin{array}{l}\text { Randall } \\
\text { Woltjer, } \\
\text { MD, PhD }\end{array}$ & $\begin{array}{l}\text { Oregon Health \& } \\
\text { Science } \\
\text { University, } \\
\text { Portland }\end{array}$ & Author & $\begin{array}{l}\text { Interpretation of the data, } \\
\text { major role in acquisition of } \\
\text { data, revising the } \\
\text { manuscript }\end{array}$ \\
\hline $\begin{array}{l}\text { Nicholas } \\
\text { Stienstra, } \\
\text { MD }\end{array}$ & $\begin{array}{l}\text { Oregon Health \& } \\
\text { Science } \\
\text { University, } \\
\text { Portland }\end{array}$ & Author & $\begin{array}{l}\text { Major role in acquisition of } \\
\text { data, revising the } \\
\text { manuscript }\end{array}$ \\
\hline $\begin{array}{l}\text { Elizabeth } \\
\text { Sun, MD }\end{array}$ & $\begin{array}{l}\text { Oregon Health \& } \\
\text { Science } \\
\text { University, } \\
\text { Portland }\end{array}$ & Author & $\begin{array}{l}\text { Major role in acquisition of } \\
\text { data, revising the } \\
\text { manuscript }\end{array}$ \\
\hline $\begin{array}{l}\text { Vijayshree } \\
\text { Yadav, MD }\end{array}$ & $\begin{array}{l}\text { Oregon Health \& } \\
\text { Science } \\
\text { University, } \\
\text { Portland }\end{array}$ & Author & $\begin{array}{l}\text { Design and } \\
\text { conceptualization } \\
\text { of the study, major } \\
\text { role in acquisition } \\
\text { of data, revising the } \\
\text { manuscript }\end{array}$ \\
\hline
\end{tabular}

\section{References}

1. Hajj-Ali RA, Singhal AB, Benseler S, Molloy E, Calabrese LH. Primary angiitis of the CNS. Lancet Neurol 2011;10:561-572.

2. Salvarani C, Brown RD, Calamia KT, et al. Primary central nervous system vasculitis: analysis of 101 patients. Ann Neurol 2007;62:442-451.

3. Torres J, Loomis C, Cucchiara B, Smith M, Messé S. Diagnostic yield and safety of brain biopsy for suspected primary central nervous system Angiitis. Stroke 2016;47:2127-2129.

4. Salvarani C, Brown RD, Calamia KT, et al. Primary central nervous system vasculitis presenting with intracranial hemorrhage. Arthritis Rheum 2011;63:3598-3606.

5. Boulouis G, de Boysson H, Zuber M, et al. Primary angiitis of the central nervous system: magnetic resonance imaging spectrum of parenchymal, meningeal, and vascular lesions at baseline. Stroke 2017;48:1248-1255.

6. Calabrese LH, Dodick DW, Schwedt TJ, Singhal AB. Narrative review: reversible cerebral vasoconstriction syndromes. Ann Intern Med 2007;146:34-44.

7. de Boysson H, Parienti J-J, Mawet J, et al. Primary angiitis of the CNS and reversible cerebral vasoconstriction syndrome: a comparative study. Neurology 2018;91:e1468-e1478.

8. Singhal AB, Topcuoglu MA, Fok JW, et al. Reversible cerebral vasoconstriction syndromes and primary angiitis of the central nervous system: clinical, imaging, and angiographic comparison. Ann Neurol 2016;79:882-894.

9. Singhal AB, Hajj-Ali RA, Topcuoglu MA, et al. Reversible cerebral vasoconstriction syndromes: analysis of 139 cases. Arch Neurol 2011;68:1005-1012.

10. Ducros A, Boukobza M, Porcher R, Sarov M, Valade D, Bousser M-G. The clinical and radiological spectrum of reversible cerebral vasoconstriction syndrome. A prospective series of 67 patients. Brain J Neurol 2007;130:3091-3101.

11. Vollmer TL, Guarnaccia J, Harrington W, Pacia SV, Petroff OA. Idiopathic granulomatous angiitis of the central nervous system: diagnostic challenges. Arch Neurol 1993;50:925-930. 


\section{Neurology}

\section{Pearls \& Oy-sters: Primary angiitis of the CNS presenting with recurrent intracranial hemorrhage}

Jessica Rice, Randall Woltjer, Nicholas Stienstra, et al.

Neurology 2020;94;e992-e995 Published Online before print February 10, 2020

DOI 10.1212/WNL.0000000000009047

This information is current as of February 10, 2020

\section{Updated Information \&} Services

References

Subspecialty Collections

Permissions \& Licensing

Reprints including high resolution figures, can be found at: http://n.neurology.org/content/94/9/e992.full

This article cites 11 articles, 3 of which you can access for free at: http://n.neurology.org/content/94/9/e992.full\#ref-list-1

This article, along with others on similar topics, appears in the following collection(s):

All Clinical Neurology

http://n.neurology.org/cgi/collection/all_clinical_neurology Intracerebral hemorrhage

http://n.neurology.org/cgi/collection/intracerebral_hemorrhage Stroke in young adults

http://n.neurology.org/cgi/collection/stroke_in_young_adults Vasculitis

http://n.neurology.org/cgi/collection/vasculitis

Information about reproducing this article in parts (figures,tables) or in its entirety can be found online at:

http://www.neurology.org/about/about_the_journal\#permissions

Information about ordering reprints can be found online:

http://n.neurology.org/subscribers/advertise

Neurology ${ }^{\circledR}$ is the official journal of the American Academy of Neurology. Published continuously since 1951, it is now a weekly with 48 issues per year. Copyright @ 2020 American Academy of Neurology. All rights reserved. Print ISSN: 0028-3878. Online ISSN: 1526-632X.

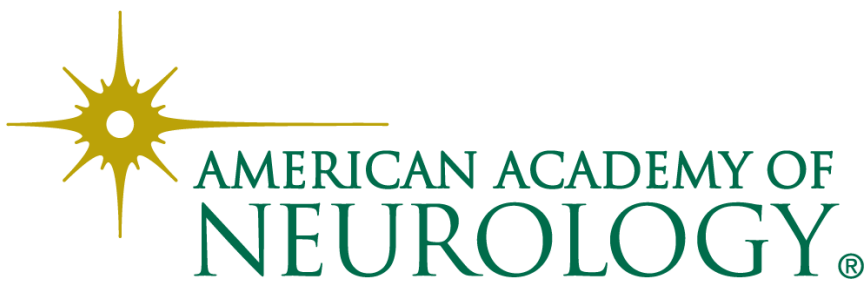

